\title{
The octahedral concept and cubic triaxiality in assessment of secondary stress state
}

\author{
Mihaela Toderas ${ }^{1 * \otimes(1)}$ \\ ${ }^{1}$ University of Petrosani, Petrosani, 332006, Romania \\ *Corresponding author: e-mail toderasmihaela@yahoo.com, tel. +40741501143
}

\begin{abstract}
Purpose. The opportunities offered by rock mechanics as a science are not fully and efficiently applied in the design and assessment of underground constructions performed in salt massifs, especially in the efficient design and long-term lifetime of the geometrical elements that characterize the exploitation method with rooms and pillars. It can be asserted that such a conventional limitation of the possibilities of rock mechanics, is due to some gaps, the lack of a fundamental theoretical experimental theory regarding the three-dimensional behavior of the rock mass.

Methods. The mechanical behavior of the salt was studied under triaxial conditions. The conventional triaxial method was supplemented with a three-dimensional analysis $\sigma-\varepsilon$ of salt massif and of rooms and pillars exploitation complex by cubic triaxiality. The deformation behavior of the salt was studied through the assessment of both cylindrical triaxial and cubic triaxial.

Findings. Analytically, based on the cubic triaxial experiments according to the octahedral concept, deformation and rheological properties of salt, results that a salt massif can be characterized in terms of the natural stress state value, by three types of zones: stable, transition and unstable.

Originality. Based on the octahedral geomechanical parameters, an analytical model for the characterization of salt massifs has been proposed, a model that has been verified both by laboratory research by the instrumentality of modelling and also by in situ measurements. In this context, it resulted that for the analyzed salt with the highest resistance, the octahedral strength does not exceed 5.6 MPa and, therefore, it is dangerous to use in the salt mines field design values of 2 to 5 times higher than the real value.

Practical implications. The determination of stress - deformation natural state is related to the highlighting of the contour or limits of the zones situated in a certain state (in triaxial context) with the consideration of the determinative anisotropy, namely, of strength and deformation anisotropy, as well as of the rheological behavior of in situ salt.
\end{abstract}

Keywords: octahedral concept, triaxiality, stress state, pillar, salt, rheology, interaction

\section{Introduction}

Ensuring the stability of the underground voids created after the exploitation of the solid salt, requires some complex studies in order to know the geomechanical characteristics, the salt behavior on the micro and macroscopic scale, as well as the rocks in which the deposit is quarried. A particular importance in this regard, is the study of dilatancy phenomenon and especially the involvement of the time factor in order to assess the rheological characteristics and parameters, sizes through which the period of maintaining the stability of the underground structures during the exploitation period, but also after, can be appreciated [1]-[5].

In the stability computations of the salt massif, its essential particularities must be evaluated, namely the rheological properties, the nonlinear character of its stress - deformation $(\sigma-\varepsilon)$ behavior, the dilatancy phenomenon under the action of shear stresses. If the state equation (the behavior equation) does not describe the three stages of creep, then, in order to be able to solve mathematically the stability issue, the stress deformation state must be established the first, and after which the condition of long-term strength is required. As a long-term strength condition, the criterion that characterizes satisfactorily the salt strength under an instantaneous load can be used. In this case, in the salt strength condition, the value of long-term strength will be introduced instead of the instantaneous characteristics (at $t=0$ ) [6]-[9].

In the current context, it is found that the opportunities of rock mechanics regarded as science, is not fully applied effectively in the issues of designing and assessment the stability of underground constructions achieved in salt massifs, but especially as regards the needles for an efficient and lasting design of the geometric and strength elements that characterize the exploitation method with rooms and 
pillars. Such conventional limitation of the possibilities of rock mechanics, is attributed to the deficiency of a fundamental theoretical - experimental theory with reference to the three-dimensional behavior of massif. Both the uniaxial and triaxial cylindrical tests, provide data regarding the strength of massif, salt deformation behavior, but these are insufficient to obtain the information necessary for the geomechanical characterization in the context of threedimensional analysis, the evaluation of salt massif - exploitation method interaction, assessment of the rheological behavior in this interaction, assessment and correlation the secondary stress - deformation state with the pillars and floors stability, type and depth exploitation, the application of analytical modelling using the numerical computation methods, for example, finite elements method or boundary elements method [3], [10].

In order to be able to use appropriately the offered theories by the rock mechanics through which the studied issue can be as real as possible identified, it is necessary to approach it in the octahedral manner. We consider that the use of octahedral concept leads us through theory and experiment to the possibility of characterizing the salt massif by assessment the compressive and shear octahedral strength, the rheological deformation characteristics (viscous-elastic, viscous-plastic) by approaching laboratory research in the context of cubic triaxiality, assess the correlations between the distribution of stress - deformation state (natural stress state; secondary stress state) of pillars and floors, with the possibility to insure their stability and taking into account the basic factors that determine an optimum extraction velocity. Such a design can be performed only based on analytical experimental research (laboratory or in situ) and using numerical computation methods [3], [11].

As a methodology, it must be developed in a logical sequence and finished with a program by evaluating the main geomechanical characteristics and rheological behavior of salt rock; characterization of salt massif depending on natural stress state; creating a model for the analysis of secondary stress - deformation state of exploitation system that will ultimately lead to the assessment of optimal geometrical parameters of pillar - room elements.

\section{The octahedral concept and cubic triaxiality}

Octahedral characterization of stress - deformation state of salt can be expressed through relationships (1) (Fig. 1):

$$
\begin{aligned}
& \tau_{o c t}=\frac{1}{3} \sqrt{\left(\sigma_{1}-\sigma_{2}\right)^{2}+\left(\sigma_{2}-\sigma_{3}\right)^{2}+\left(\sigma_{3}-\sigma_{1}\right)^{2}} ; \\
& \sigma_{m}=\frac{1}{3}\left(\sigma_{1}+\sigma_{2}+\sigma_{3}\right) ; \\
& \gamma_{o c t}=\frac{1}{3} \sqrt{\left(\varepsilon_{1}-\varepsilon_{2}\right)^{2}+\left(\varepsilon_{2}-\varepsilon_{3}\right)^{2}+\left(\varepsilon_{3}-\varepsilon_{1}\right)^{2}} ; \\
& \varepsilon_{m}=\frac{1}{3}\left(\varepsilon_{1}+\varepsilon_{2}+\varepsilon_{3}\right) .
\end{aligned}
$$

Normal stresses $\sigma_{1}, \sigma_{2}$ and $\sigma_{3}$, main normal deformations $\varepsilon_{1}, \varepsilon_{2}$ and $\varepsilon_{3}$, as well as the rates of main normal stresses $\sigma_{1}, \sigma_{2}, \sigma_{3}$, respectively the rates of main normal deformations $\dot{\varepsilon}_{1}, \stackrel{\circ}{\varepsilon}_{2}, \stackrel{\circ}{\varepsilon}_{3}$ are determined as components of stress state tensor $\left|T_{\sigma}\right|$, deformation state tensor $\left|T_{\varepsilon}\right|$, respectively stress state rate tensor $\left(\left|T_{\sigma}^{\circ}\right|\right)$ and strain state tensor $\left(\left|T_{\varepsilon}^{\circ}\right|\right)$ by means of cubic triaxial test. Thereby, the cubic triaxial equipment (Fig. 2), designed and performed in the Rock Mechanics Laboratory from the University of Petrosani, confers the possibility to control and measure continuously, but also simultaneously the stresses and deformations, in such a way as to establish the involved parameters in octahedral concept.

(a)

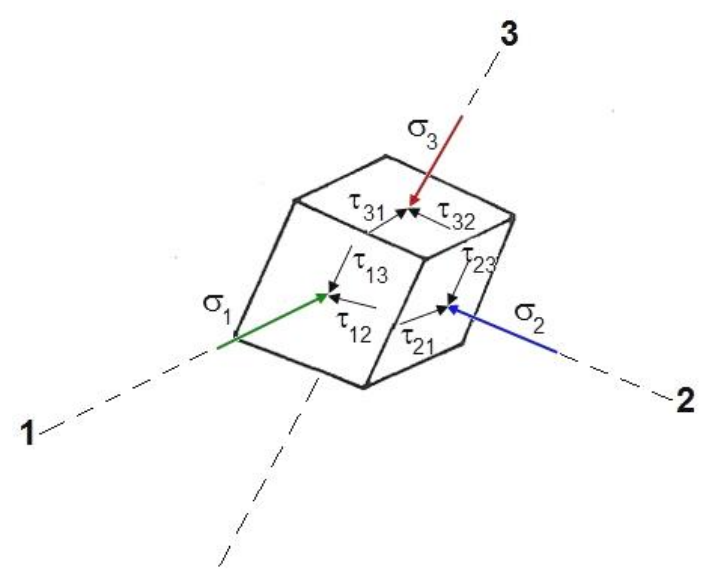

(b)

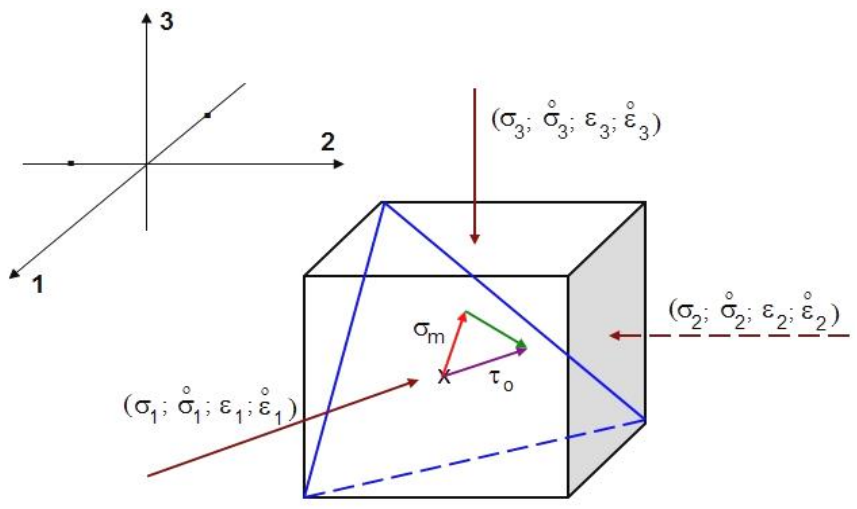

Figure 1. The principle of cubic triaxial test: (a) stress - deformation tensor; (b) the 12 components in the orientation of the main axes

\section{Parameters that can be established by cubic triaxial test}

The use of cubic triaxial equipment offers much more real possibilities for studying the deformation behavior of salt, in the sense that significantly different results are obtained comparatively to those resulting by conventional methods. Thus, the main parameters involved in the analysis of the stability of room - pillar system through the octahedral theory can be established, namely: octahedral shear strength; instantaneous elastic - plastic characteristics; characteristic curve $\left(\tau_{o c t}-\sigma_{m}\right)$; time - deformation rate and load rate dependence; the influence of intermediate component of secondary stress state $\left(\sigma_{2}\right)$ on the stability; specifying the rheological behavior and the model that can be considered in the assessment of the secondary stress - deformation state. 
(a)

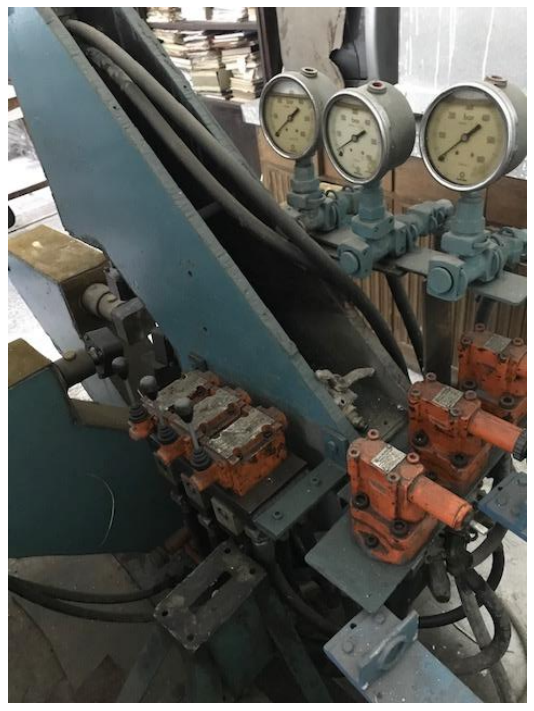

(b)

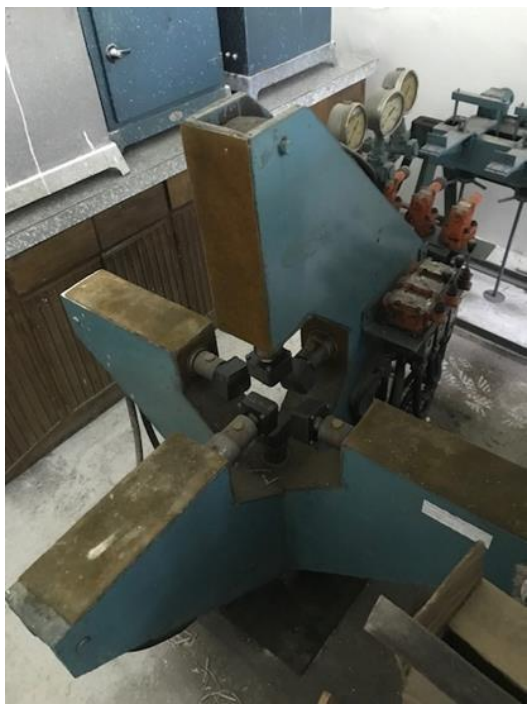

(c)

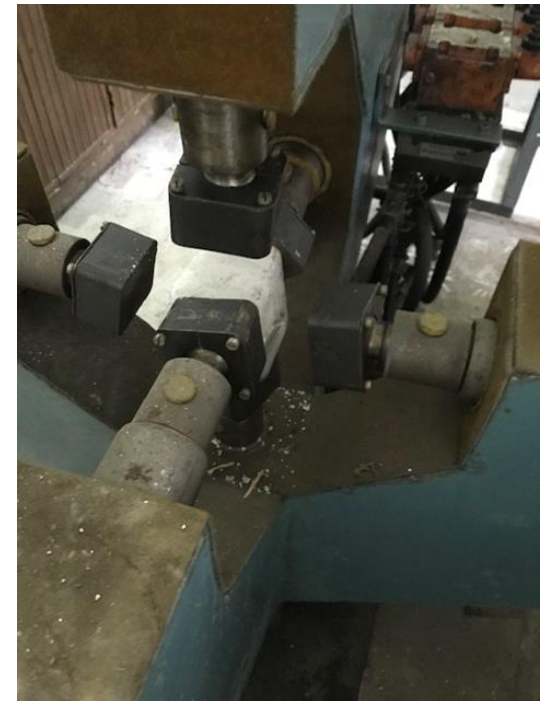

Figure 2. Cubic triaxial equipment: (a) measuring system; (b) and (c) fixing system of salt samples

Such an assertion is confirmed by the following case study performed on the rock salt type, that (Fig. 3): from petrographic point of view it has a macro or microcrystalline appearance, polluted with diagenetic dispersions consisting of clays, marbles, sandstones and crystalline limestones etc. in the form of disseminations, impregnations, banded inclusions or enclaves of different sizes (inclusions of sterile, over $0.5 \mathrm{~m}$ in diameters, may occur in the form of banded intercalations or brecciated fragments, resulting from halokinetic deformations of rock salt); the texture is varved, and its structure is homeo - or heteroblastic.

(a)

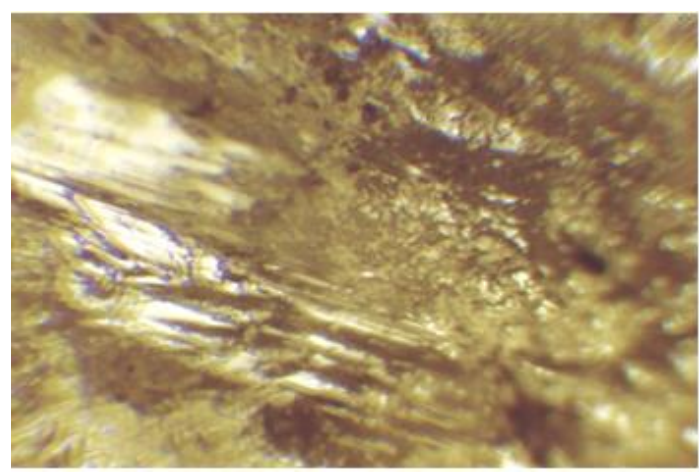

(c)

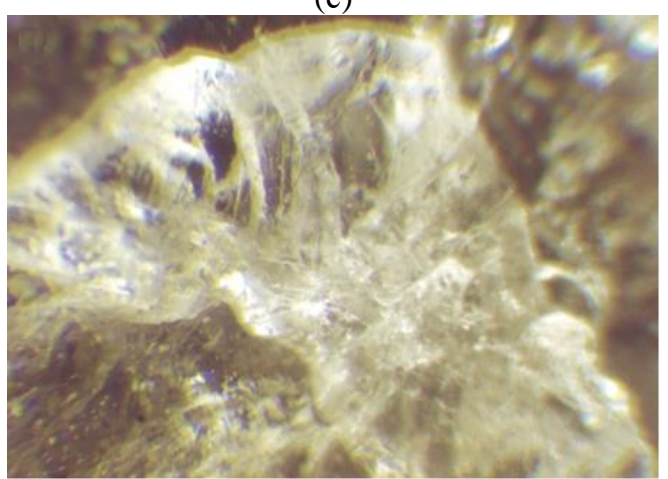

In the mass of the salt disseminated and conglomeratic elements formed of hard, exotic rocks (crystalline green schist, quartzites, limestones and Mesozoic crystalline limestones) appear.

The type of studied rock salt has a hardness of 2.5-2.6 to 3 on the Mohs scale. In relation to the above, a study in terms of Poisson coefficient $(\mu)$ value using conventional methods (Fig. 4) and by proposed method, namely cubic triaxiality (Fig. 5), has been considered to be necessary too. deformation state. (b)

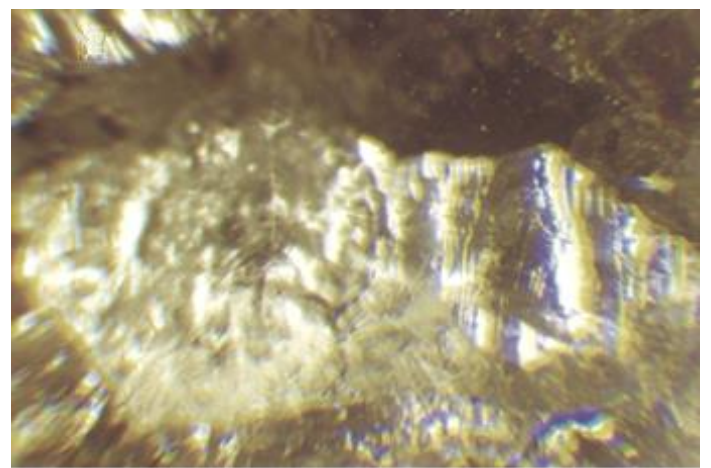

(d)

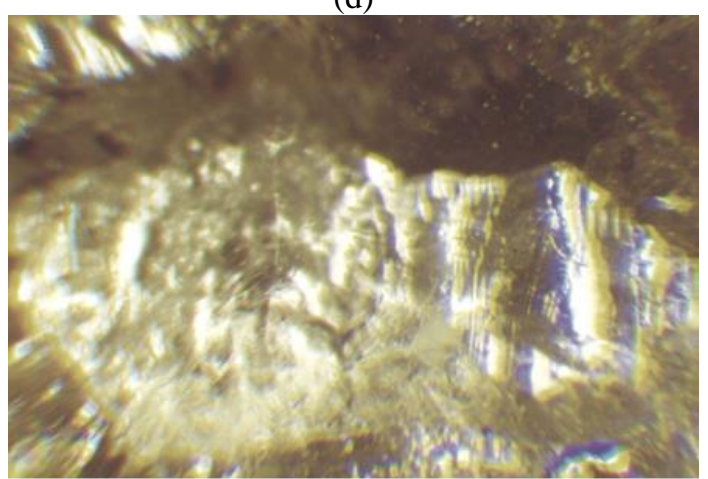

Figure 3. Micro stereoscopic analysis: (a) microcrystalline salt associated with argilite minerals; (b) large salt crystals developed with an irregular contour; (c) partially laminated -fibrous salt phenocrysts; (d) presence of partially fibrous salt macrocrysts 


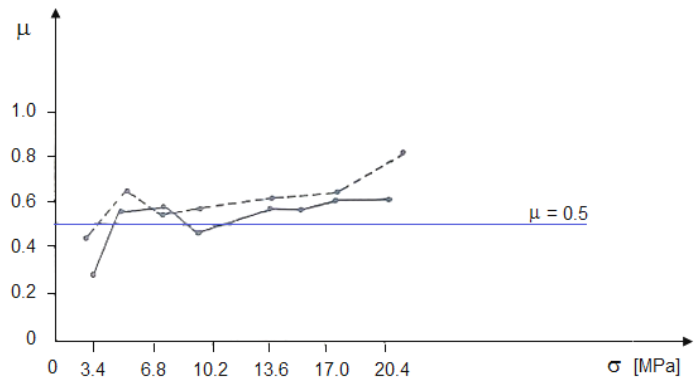

Figure 4. Variation of Poisson's coefficient by the classical methodology for analysed salt

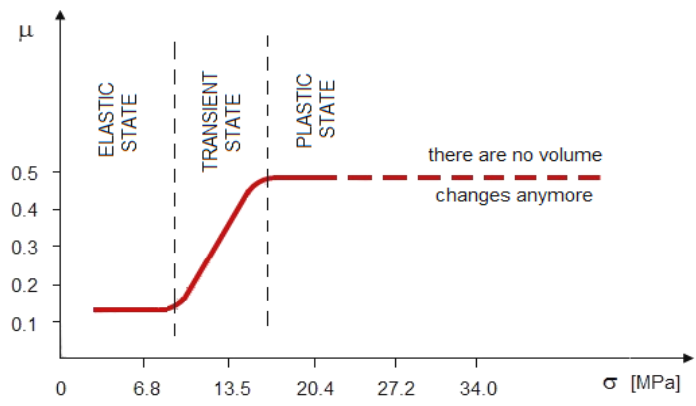

Figure 5. Variation of Poissons's coefficient in case of cubic triaxiality for analysed salt

The results showed that the value of Poisson's coefficient $(\mu)$ obtained by conventional method [7], [12]-[14] is not a constant value, but it varies according to the stress (Fig. 4). In the case of triaxial cubic test, the value of Poisson's coefficient $(\mu)$ is a constant (Fig. 5), and the change of this coefficient from the value 0.12 for the elastic area to the value of 0.43 for the plastic area is direct, clearly indicating a transition of the deformation behavior of the type of studied salt from the elastic area to the plastic one. The octahedral shear strenght $\left(\tau_{o c t}\right)$ is a characteristics that can be established by cubic triaxiality; this strenght offers the possibility of calculating the plastic flow rate $\left(\stackrel{\circ}{\varepsilon}_{c p}\right)$ and viscous-plastic flow rate $\left(\stackrel{\circ}{\varepsilon}_{v p}\right)$, specifying the maximum limit of the octahedral stress at which the salt state can be identified with its flow state.

Establishing and knowing this strenght offers the possibility to separate or distinguish the viscous-plastic deformations from the elastic-viscous ones of the tested salt (Fig. 6), situation for which $\tau_{\text {oct } \max }=6 \mathrm{MPa}$, and the viscousplastic flow rate is given by the slope of the straight line of the curve. It should be noted that the octahedral shear strenght $\left(\tau_{\text {foct }}\right)$ of the most resistant studied salt not exceed the value of 5.6 $\mathrm{MPa}$ and as a result, in the design is irrational to use values of 2 to 5 times higher than the true value.

Characteristic curve $\tau_{o c t}-\sigma_{m}$ (Fig. 7) gives us the possibility to specify the existant stress condition and the stability perspective offered by the massif can be analyzed; allows to establish the structural safety of the room - pillar exploitation system, in the sense that if it will be established that the octahedral strenght value $\left(\tau_{\text {oct }}\right)$ which tends to zero, then, from the point of view of the natural stress state the massif offers a stability, and if $\tau_{o c t}$ tends towards a maximum value $\left(\tau_{f o c t}\right)$ then the massif is incompetent and as a result, adequate sizing measures are required, by using safety factors corresponding to such conditions.

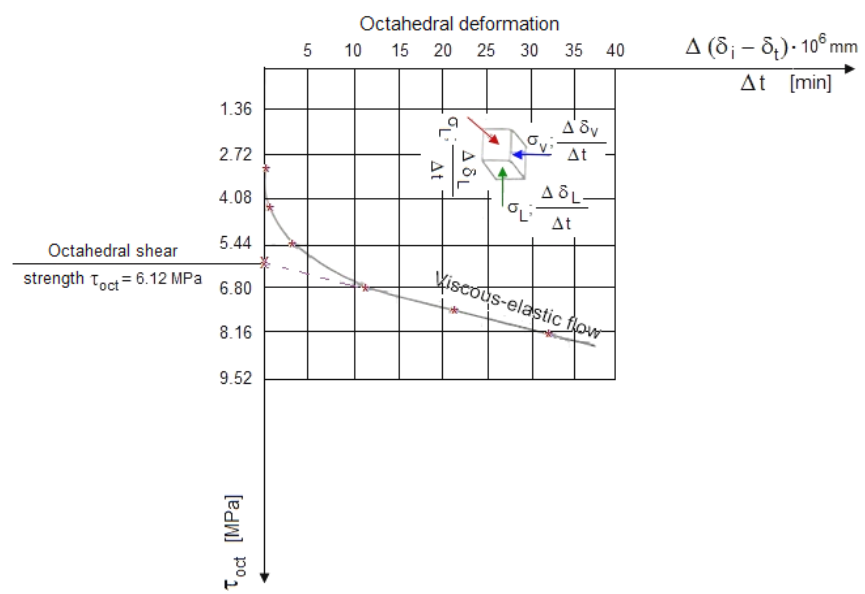

Figure 6. Establishing of octahedral shear strength $\left(\tau_{f o c t}\right)$ through cubic triaxiality for studied salt

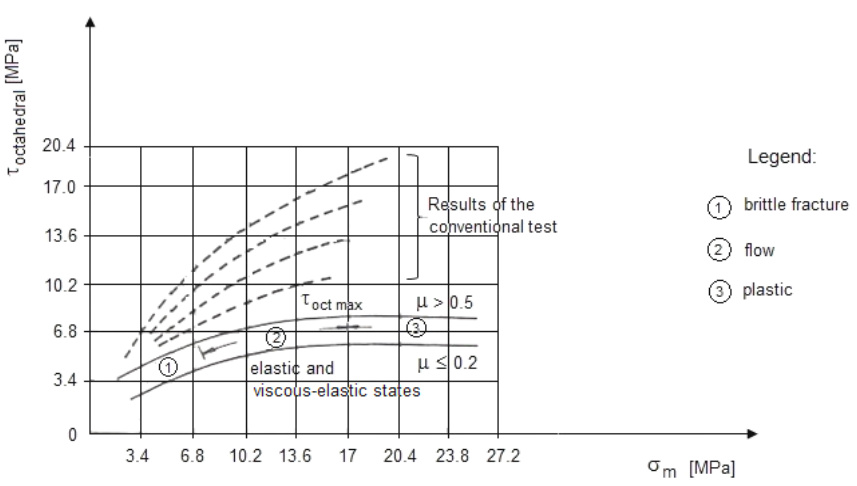

Figure 7. Characteristic curves $\tau_{o c t}-\sigma_{m}$ for studied salt

Characteristic curve $\tau_{\text {oct }}-\sigma_{m}$ (Fig. 7) gives us the possibility to specify the existant stress condition and the stability perspective offered by the massif can be analyzed; allows to establish the structural safety of the room - pillar exploitation system, in the sense that if it will be established that the octahedral strenght value $\left(\tau_{\text {oct }}\right)$ which tends to zero, then, from the point of view of the natural stress state the massif offers a stability, and if $\tau_{\text {oct }}$ tends towards a maximum value $\left(\tau_{f o c t}\right)$ then the massif is incompetent and as a result, adequate sizing measures are required, by using safety factors corresponding to such conditions. Determining the $\tau_{o c t}-\sigma_{m}$ correlation allows a new definition of the strenght of salt massif, that is "the limit strenght", as a stress state for which Poisson's coefficient $(\mu)$ reaches certain values, namely:

- if $\mu \leq 0.2$, then we talk about elastic strenght;

- if $0.2 \leq \mu \leq 0.5$, then we talk about flow or plastic strenght.

\section{Octahedral concept in the assessment of the secondary stress - deformation state}

\subsection{Rheological behavior characterization of a salt massif in the context of interaction with pillar - room - floor exploitation system}

The involvements of the time parameter in the analysis of stress - deformation state of pillars and floors as the increasing of exploitation depth, and in the same octahedral framework, are considered to be reproduced by the rheological model resulting from the serial linking of the Maxwell, Kelvin, viscousplastic and elastic - plastic models (Fig. 8) [3], [9], [15], [17]. 
(a)

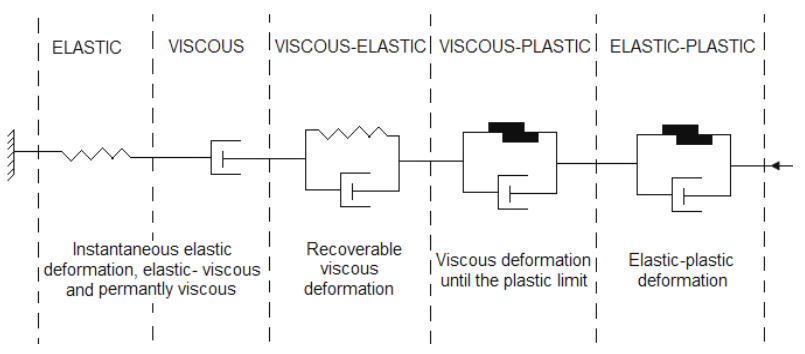

(b)

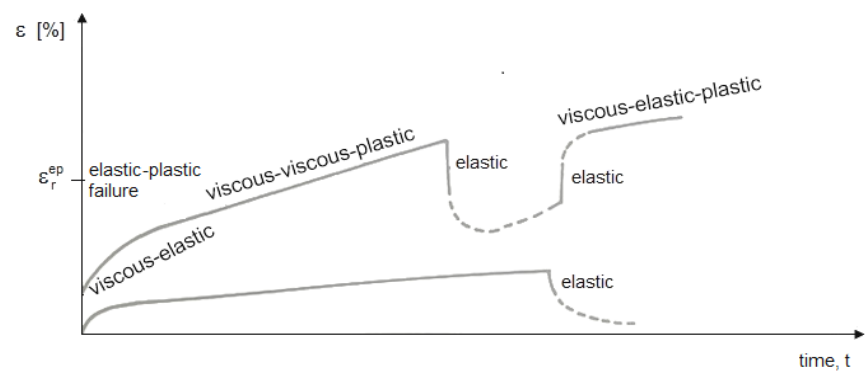

Figure 8. Rheological behavior of studied salt rock in the context of salt massif - exploitation system interaction: (a) proposed rheological model; (b) creep curve of proposed rheological model

The constitutive equation of the model was established at the form:

$$
\{\sigma\}=\int_{-\infty}^{t} D\left(t-t^{\prime}\right) \frac{\partial}{\partial t^{\prime}}\left\{\varepsilon^{T}-\varepsilon^{v p}\right\}
$$

where:

$$
\varepsilon^{T}=\varepsilon^{v e} \cdot \varepsilon^{v p}
$$

$\varepsilon^{\nu e}-$ viscous-elastic deformations for $\tau_{o c t} \leq \tau_{o c t f}$ :

$\varepsilon_{i j}^{v e}=\frac{S_{i j}}{2}\left\{\frac{1}{G_{0}}+\frac{1}{G_{1}}\left[1-\exp \left(-\frac{G_{1}}{\eta_{1}} t\right)\right]\right\}$;

$S_{i j}=\sigma_{i j}-\frac{1}{3} \delta_{i j} \sigma_{m}$

$\varepsilon^{v p}-$ the viscous-plastic deformations for $\tau_{o c t}>\tau_{o c t f}$ :

$\varepsilon_{i j}^{v p}=\left(1-\frac{\tau_{o c t f}}{\tau_{o c t}}\right) S_{i j}\left[\frac{1}{2} \eta_{4}+\frac{1-\exp \left(-\frac{G_{2}}{\eta_{2}} t\right)}{2 G_{2}}+\frac{1-\exp \left(-\frac{G_{3}}{\eta_{3}} t\right)}{2 G_{3}}\right]$.

Afterwards, the matrix $\left[D\left(t-t^{\prime}\right)\right]$ can be created, of the form:

$$
\left[D\left(t-t^{\prime}\right)\right]=\left[\begin{array}{ccc}
\frac{4}{3 G\left(t-t^{\prime}\right)}+K\left(t-t^{\prime}\right) & K\left(t-t^{\prime}\right)-\frac{2}{3 G\left(t-t^{\prime}\right)} & 0 \\
K\left(t-t^{\prime}\right)-\frac{2}{3 G\left(t-t^{\prime}\right)} & \frac{4}{3 G\left(t-t^{\prime}\right)}+K\left(t-t^{\prime}\right) & 0 \\
0 & 0 & G\left(t-t^{\prime}\right)
\end{array}\right]
$$

where:

$K\left(t-t^{\prime}\right)$ - the elastic stiffness matrix, of the form:

$$
\int_{-\infty} K\left(t-t^{\prime}\right) \frac{\partial}{\partial t^{\prime}} d t^{\prime}
$$

\section{Results and discussion}

\subsection{Natural stress - deformation state}

The studied salt type has also been analysed in the geomechanics laboratory from the point of view of physical, strength and deformation characteristics (Fig. 9 and 10).

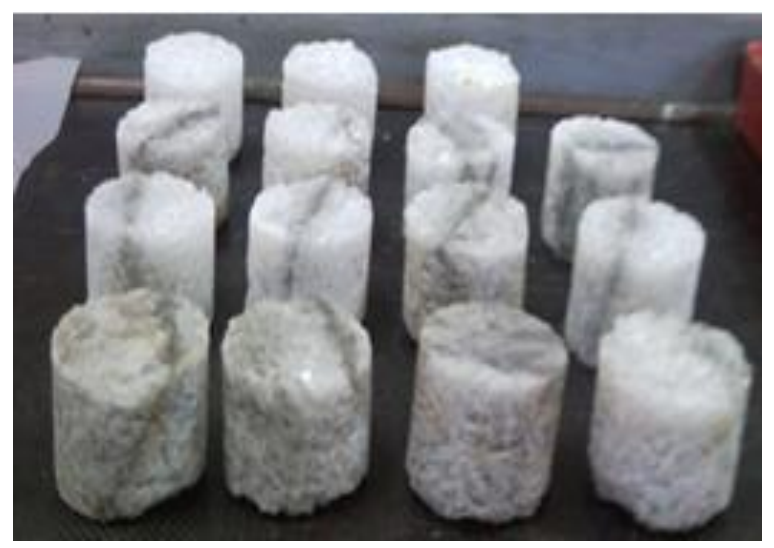

Figure 9. Salt samples used to determine the strength and deformation characteristics and to study the rheological behavior

Based on the values of uniaxial compressive breaking strength, this type of salt can be classified in the class of low strength rocks, according to existing classifications from literature [1], [11], [12], [18], [19] showing the following values of cohesion and internal friction angle established either by shear and triaxial tests: $c=2.65 \mathrm{MPa}$ and $\varphi=11^{\circ}$ respectively, $c_{\text {triaxial }}=7.9 \mathrm{MPa}$ and $\varphi_{\text {triaxial }}=10^{\circ}$, typical of such rocks. Triaxial compressive strength, axial symmetrical or cylindrical has average values ranging between $22.1-29.58 \mathrm{MPa}$, depending by increase of lateral stresses $\sigma_{x}=\sigma_{y}$ in the field of 2.5 to $7.5 \mathrm{MPa}$; this fact reveals a small and non-linear increase of this strength in relation to the application of lateral stresses.

Analysing the strain behavior according to all obtained parameters from the static load tests, we can say that this salt has an inelastic behavior type, respectively viscous - plastic, fact confirmed both by the dilatancy parameters (Fig. 11).

Both for compression and deformation tests, it was proved that salt strength depends on deformation rate; breakage or fracture occurred only when a certain deformation rate was exceeded. At the same time, the appearance and orientation of the cracks revealed that the salt rock is requested by an inhomogeneous stress state, especially characterized by the occurrence of a tensile stresses (also revealed by in situ observations) in the quasi - orthogonal direction with respect to the compression axis.

The appearance and manifestation of these stresses is partly due to the variation, size, shape and orientation of the constituent grain of the polycrystalline salt medium. The assessment of natural stress - deformation state represents a difficult issue, especially in the obvious situation of heterogeneous salt formation [3], [11], [17], [20].

From a theoretical point of view, the difficulty consists in the fact that in assessment of this natural state, the presence of two types of areas must be taken into account: (1) the area (or zone) where the salt rock is to the limit of stress - deformation state; (2) the area where such stress - deformation state is not reached and the salt rock has a reserve of strength (resilience). 


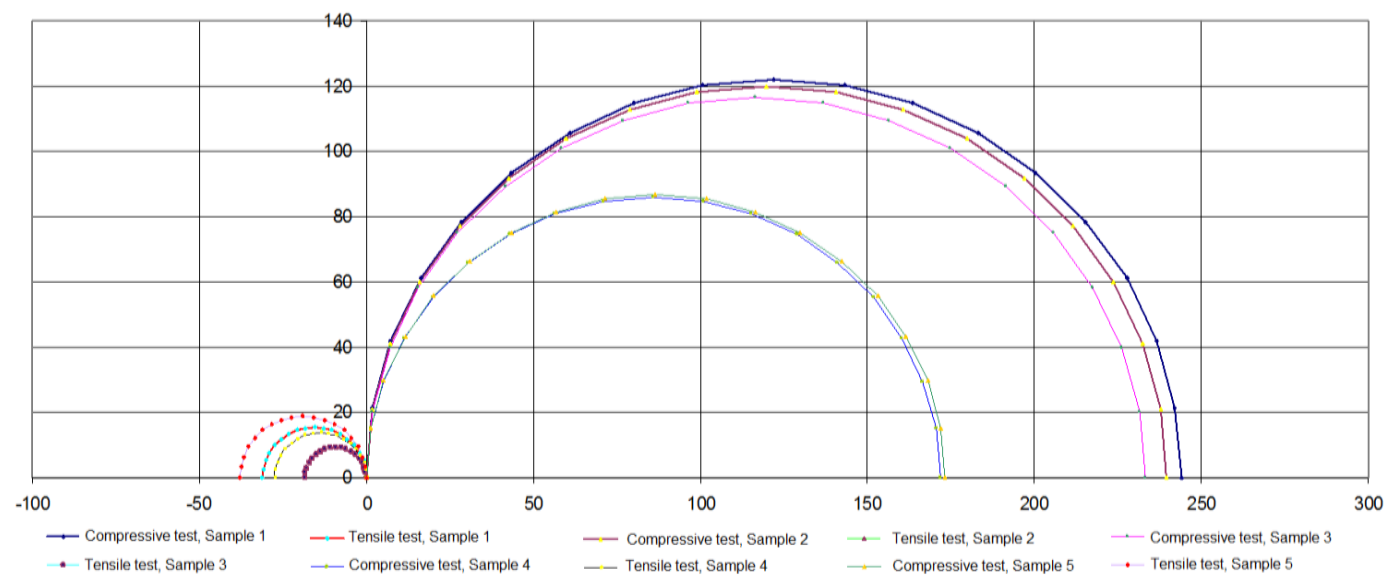

Figure 10. Determining the cohesion and the internal friction angle with Mohr's circle

(a)

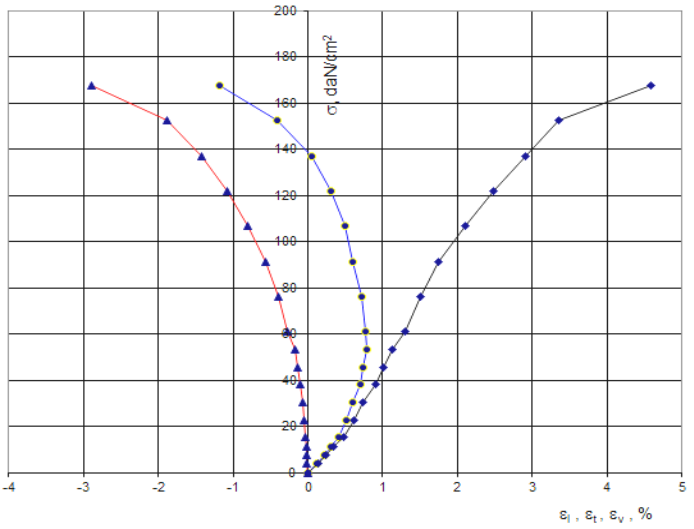

(c)

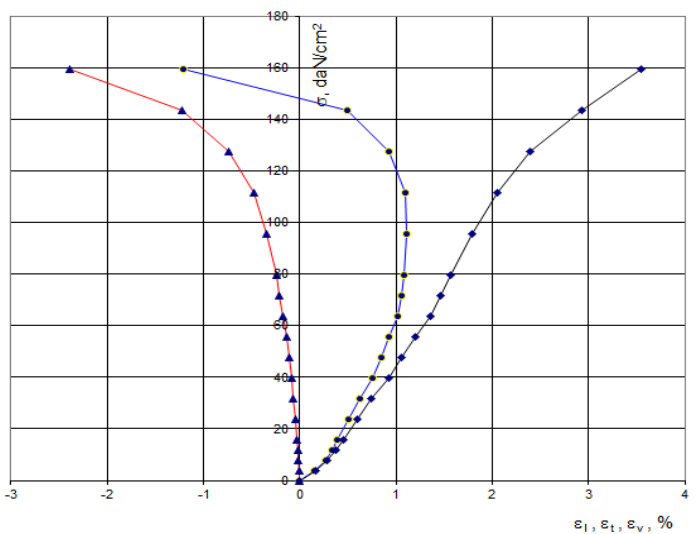

(e)

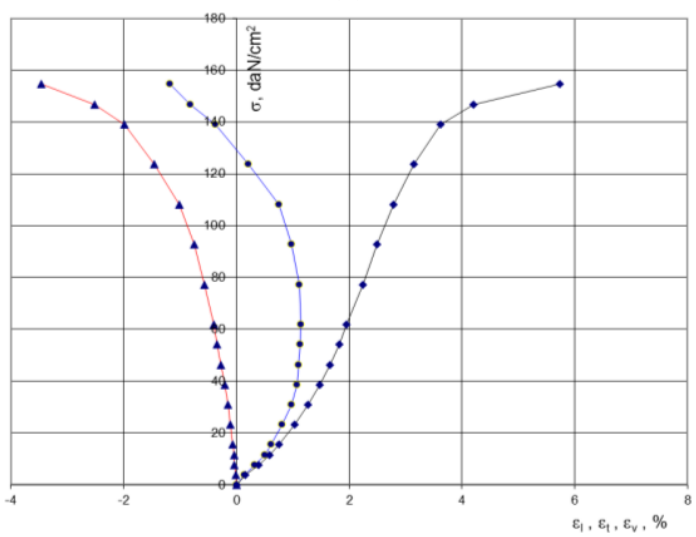

(b)

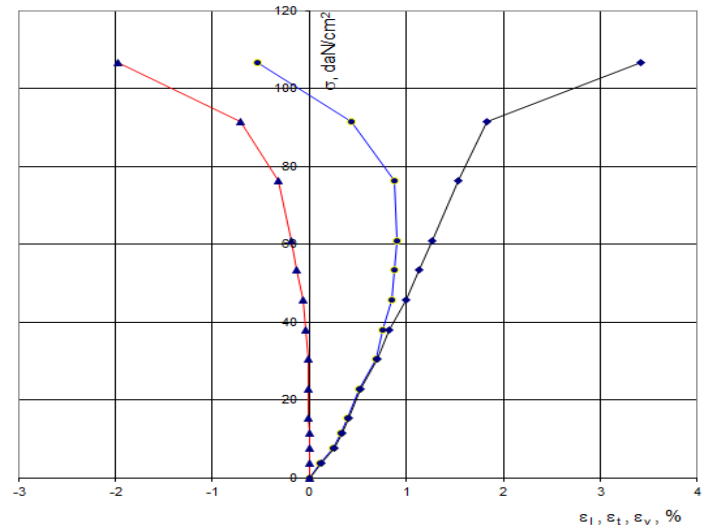

(d)

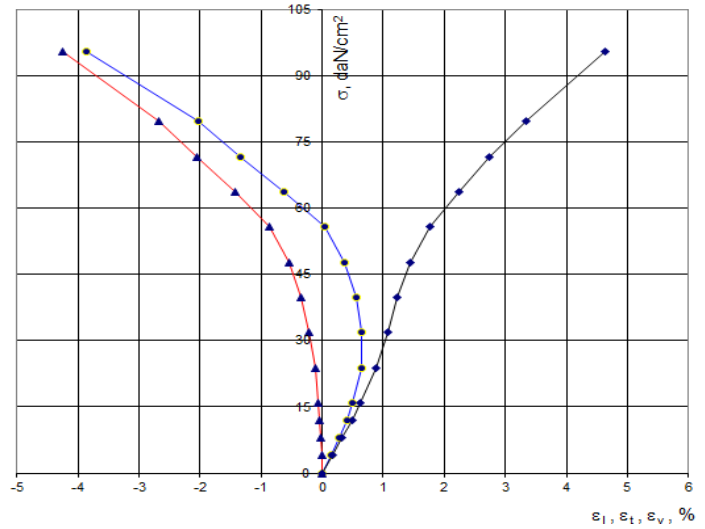

(f)

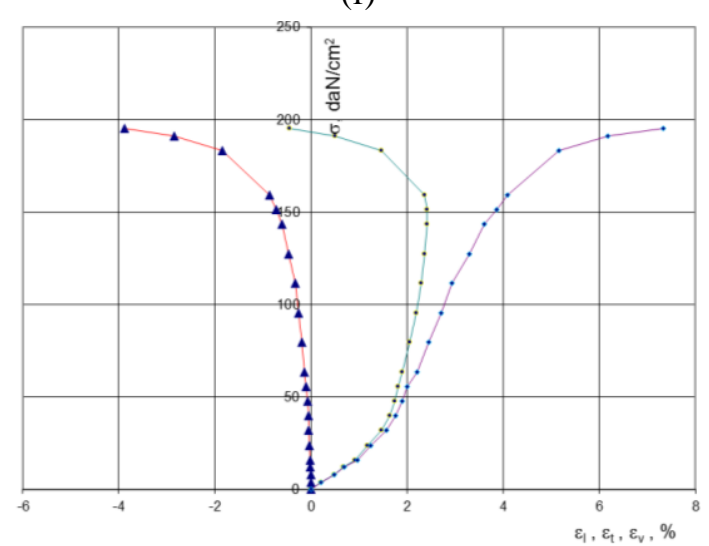

Figure 11. Dilatancy curves for different analyzed salt samples: (a) sample No. 1; (b) sample No. 2; (c) sample No. 3; (d) sample No. 4; (e) sample No. 5; $(f)$ sample No. 6 
The appearance and manifestation of these stresses is partly due to the variation, size, shape and orientation of the constituent grain of the polycrystalline salt medium. The assessment of natural stress - deformation state represents a difficult issue, especially in the obvious situation of heterogeneous salt formation [3], [11], [17], [20].

From a theoretical point of view, the difficulty consists in the fact that in assessment of this natural state, the presence of two types of areas must be taken into account: (1) the area (or zone) where the salt rock is to the limit of stress - deformation state; (2) the area where such stress - deformation state is not reached and the salt rock has a reserve of strength (resilience).

Based both on the octahedral characteristics and rheological behavior (Fig. 12 and 13) it was analytically prevail to establish some correlations between $\sigma_{z}$ and $\sigma_{0}$, through which the salt massif can be characterized from the point of view of the distinguished zones (Table 1).

Table 1. Natural stress state in salt massif

\begin{tabular}{lc}
\hline $\begin{array}{l}\text { The zone } \\
\text { of rock } \\
\text { salt massif }\end{array}$ & Natural stress state \\
\hline $\begin{array}{l}\text { Stable } \\
\text { zone }\end{array}$ & $\sigma_{0}=\sigma_{z} \pm \frac{3 G_{2} \tau_{\text {oct } f}}{2\left(G_{1}+G_{3}\right)}$ \\
\hline $\begin{array}{l}\text { Transition } \\
\text { zone }\end{array}$ & $\sigma_{0}=\sigma_{z}-\frac{3 \tau_{\text {oct } f}}{\sqrt{2}\left(G_{1}+G_{3}\right)} \cdot\left[G_{2}-G_{1} \exp \left(-\frac{G_{1}+G_{2}}{2} t\right)\right]$ \\
\hline $\begin{array}{l}\text { Unstable } \\
\text { zone }\end{array}$ & $\sigma_{0}=\frac{\mu}{1-2 \mu} \sigma_{z}$ \\
\hline
\end{tabular}

(a)

Sample 1

$\sigma_{\mathrm{rc} \mathrm{med}}=147 \mathrm{daN} / \mathrm{cm}^{2}$ $\lambda=h / d=2$

\begin{tabular}{|c|c|c|}
\hline $\begin{array}{c}\text { Level of } \\
\text { loading }\end{array}$ & $\begin{array}{c}\text { Loading } \\
\text { degree } \\
\Delta\end{array}$ & $\begin{array}{c}\text { Strength } \\
\sigma \\
{\left[\mathrm{daN} / \mathrm{cm}^{2}\right]}\end{array}$ \\
\hline & & \\
\hline $\mathrm{I}$ & 0,25 & 36,75 \\
\hline $\mathrm{II}$ & 0,3 & 44,1 \\
\hline $\mathrm{III}$ & 0,5 & 73,5 \\
\hline $\mathrm{IV}$ & 0,6 & 88,2 \\
\hline $\mathrm{V}$ & 0,7 & 102 \\
\hline $\mathrm{VI}$ & 0,8 & 117,6 \\
\hline
\end{tabular}

(b)

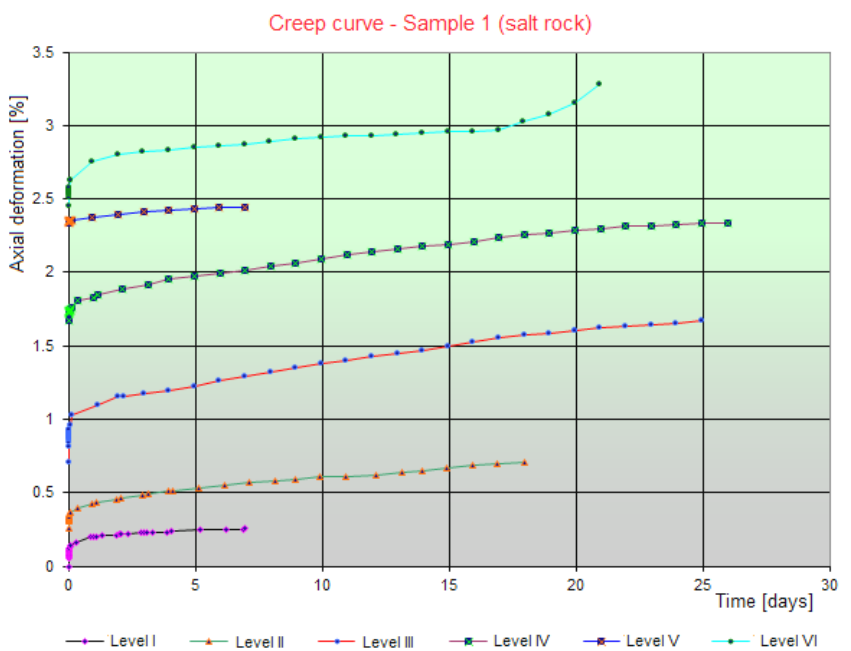

Figure 12. Loading degree of salt sample (a) and the corresponding creep curves $(b)$ (a)

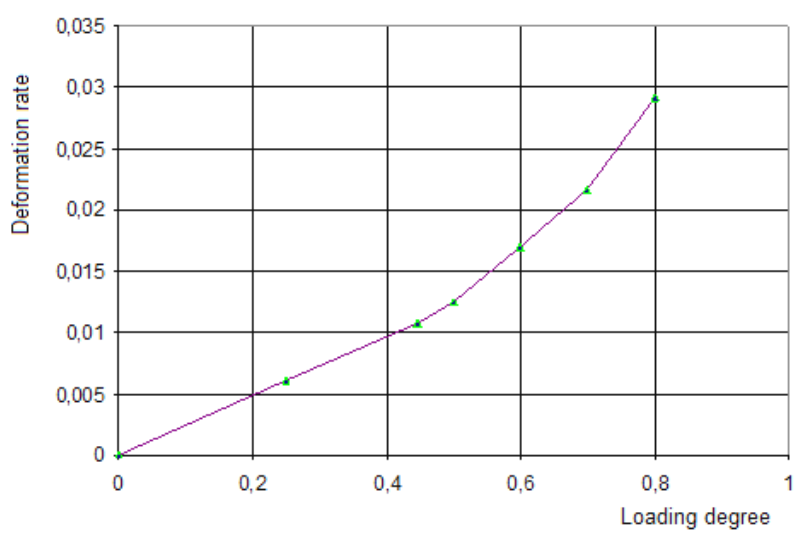

(b)

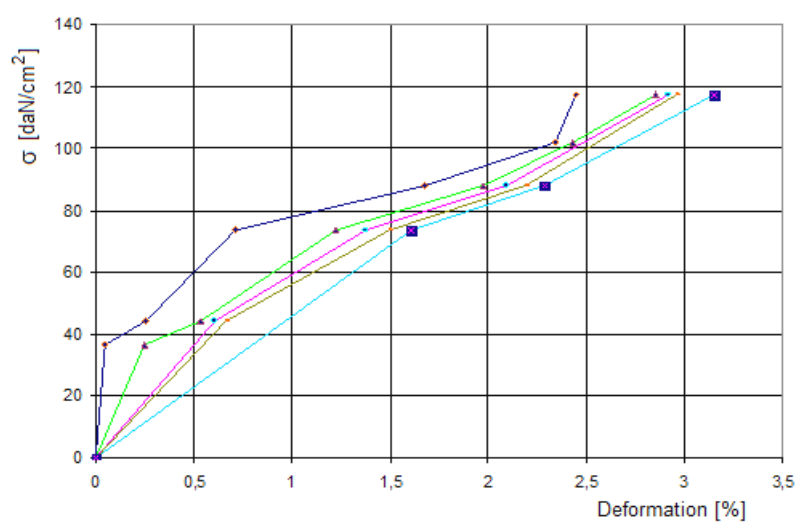

(c)

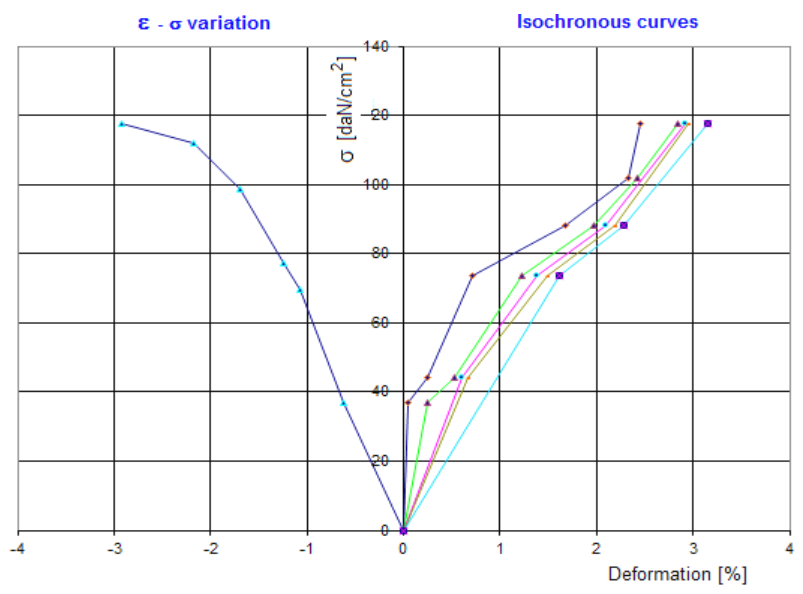

Figure 13. Interpretation of laboratory results from rheological tests performed on salt samples: (a)-variation curve of deformation rate depending on loading degree; (b) - isochronous curves for time values from 0 to 20 days; (c) - variation curve of deformation depending on level of loading

\subsection{Secondary stress - deformation state}

The parameters established in the manner specified above, completed with the laboratory researches through modelling, allowed the formulation of the effects of secondary stress - deformation state around the room - pillar system (Fig. 14) and also the criteria according to which the secondary stress - deformation state can be evaluated (Table 2) using the finite element method. 


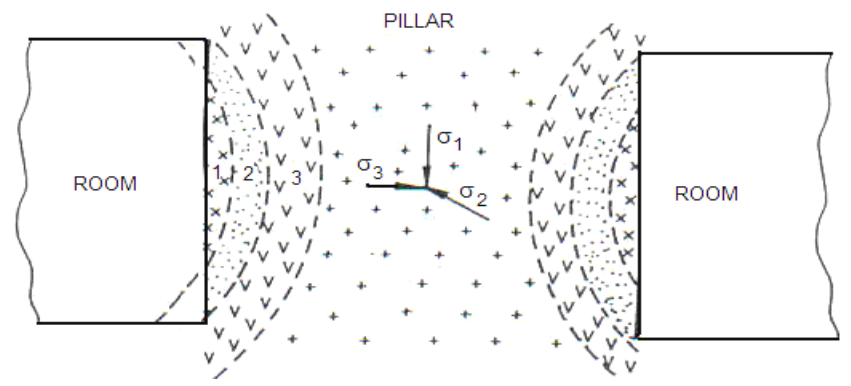

Figure 14. Effects of secondary stress - deformation state on the room - pillar system: 1 - brittle fracturing zone; 2 -flow zone - viscous state; 3-plastic zone - plastic state; 4 -elastic zone-elastic state

Table 2. Secondary stress - deformation state in octahedral concept

\begin{tabular}{|c|c|}
\hline $\begin{array}{c}\text { The zone (area) } \\
\text { of salt rock massif }\end{array}$ & Secondary stress - deformation state \\
\hline Brittle fracture zone & $\begin{array}{ll}\tau_{o c t} \approx 0 \\
\sigma_{m}>0 \\
-\varepsilon_{3}>>\left(\varepsilon_{1}+\varepsilon_{2}\right)\end{array} \quad ; \quad \begin{array}{l}\varepsilon_{m}-\text { maximum } \\
\gamma_{o c t}-\text { mimimum }\end{array}$ \\
\hline $\begin{array}{l}\text { Flow zone - } \\
\text { viscous state }\end{array}$ & $\begin{array}{l}\tau_{o c t}<\tau_{o c t f} \\
\sigma_{m}<0 \\
-\varepsilon_{3}>\left(\varepsilon_{1}+\varepsilon_{2}\right)\end{array}$ \\
\hline $\begin{array}{l}\text { Plastic zone - } \\
\text { plastic state }\end{array}$ & $\begin{array}{l}\tau_{o c t}=\tau_{o c t f} \\
\sigma_{m}>0 \\
-\varepsilon_{3} \leq\left(\varepsilon_{1}+\varepsilon_{2}\right)\end{array}$ \\
\hline $\begin{array}{l}\text { Elastic zone - } \\
\text { elastic state }\end{array}$ & $\begin{array}{ll}\tau_{o c t}<\tau_{o c t ~} f & \varepsilon_{m}-\text { maximum } \\
\sigma_{m}>0 & ; \\
-\varepsilon_{3}=\left(\varepsilon_{1}+\varepsilon_{2}\right) & \gamma_{o c t}-\text { mimimum }\end{array}$ \\
\hline
\end{tabular}

From the Figure 14, the formation of three areas is noted: brittle fracture zone evidenced on a distance of about 0.2 to $0.5 \mathrm{~m}$ around the pillar, flow zone or viscous zone, and the inelastic zone - plastic field.

These last two areas for the correctly sized pillars are reaching for up to a distance of about $1.5 \mathrm{~m}$ around them, and finally in the elastic deformation zone or elastic state. Based on the specified we can indicate the hypothetical situations that a pillar can reach until breaking namely: competent pillar and pillar in a state of flow [3], [11], [19].

\section{Conclusions}

The correctness of approaching the problem in the sense of obtaining a well-defined solution by applying the finite element method, implies an experimental and in situ laboratory verification, so as, at the basis of the computing scheme, the general representation of the analyzed phenomenon is present; for the time being, this has been done only on the basis of a relatively small number of laboratory experiments, the obtained data from observations and the results obtained by the author and provided from different researchers who have studied so far the behavior of salt from Romanian salt mine.

The analyzed salt has a heterogeneous crystalline structure, constituting a rock that can become plastic at low pressures and temperatures; the salt texture is partially oriented. The micro stereoscopic analysis revealed the following: the presence of the sintectonic transformations, in the sense that majority initial cubic crystals have a fibrous habitus, with the orientation in the direction of maximum folding pressures; the orientation of the fibrous crystals agrees with the orientation of the salt - argillaceous - bituminous breccia fragments present in the rock salt.

In the case of rocks and, implicitly, of the salts gems, which are naturally located in massif in a state of triaxial stress, the mechanical behavior is required to be studied under the conditions of triaxiality. The triaxial test reflects that the break of rocks, respectively of rock salt, strongly depends on the two components of stress (normal and shear components) for which a certain mode of break (brittle or ductile) finally corresponds, in contraposition to the methods where the break or flow depends very little on the mean normal stress.

Analyzing the deformation behavior based on the obtained parameters from the static loads tests, it was found that the studied salt type has a non-elastic behavior of elastic viscous - plastic type, fact confirmed by the dilatancy parameters. In both compression and deformation tests, it was found that the salt resistance is dependent on the deformation rate; the break or fracture occurred only when a certain deformation rate was exceeded. At the same time, the appearance and orientation of the cracks revealed that the salt is required by a heterogeneous stress state, characterized in particular by the manifestation of tensile stresses in the quasi-orthogonal direction with respect to the compression axis. The appearance and manifestation of these stresses is partly due to the variation, size, shape and orientation of the constituent granules of the polycrystalline salt medium.

On the basis of the researches and specifications, were both the experimental results obtained in laboratory and acknowledge that the value of deformation shear stress $\left(\tau_{o c t}\right)$ that occurs in salt determine, in general, structural stability of the excavations performed in salt mine. Such acknowledge is contrary to the classical concept that "depth alone" would be the deciding factors in ensuring the stability. This hypothesis has been confirmed in the literature, in the sense that it signal certain instability phenomena produced in salt mines of little depth, considered much more dangerous than in salt mines placed much deeper. Analytically, based on the triaxial cubic experiments, depending on the octahedral concept, deformation properties of salt and rheological ones, it has resulted that the salt massif can be characterized form the point of view of natural stress state value, through three types of zones: stable, transient and unstable.

An important and own conclusion of the author is that the determination of natural stress - deformation state is related to the highlighting of the contour or limits of these areas located in a certain state (in a triaxial context) taking into account of determinative anisotropy, namely the strength and deformation anisotropy, as well as of the in situ rheological behavior of salt.

Determining the secondary stress state around an underground excavation is a complex issue of Geomechanics and therefore of the mining field. Its assessment is very difficult because of the interaction of the instrumentation with the rock massif, but also expensive [3], [9], [11]. By means of in situ measurements, we can obtain information and concrete data necessary for the accurate knowledge of the problems that occur in underground and also allow for example a comparison between the stress state of the pillar and the results obtained analytically. This information obtained from the in situ measurements also allows the development of the mo- 
delling technique and the validation of the theoretical studies regarding the stress states that are manifested in underground excavations regarding the spatial problems - threedimensional ones.

Because through observations and measurements made in situ, the cumulative effect of all the decisive factors is obtained in an implicit form, the choice of the measurement methodology acquires a special importance. This one, in addition to the fact that it must ensure the correct and faithful assessment of the stress - deformation state (loads, displacements), must allow to make clarifications on the effect that would have a change of one of the decisive factors on stress deformation state (loading and manifestation displacements regime) on the underground construction safety degree.

\section{Acknowledgements}

I would like to say thank you to the geologist colleagues from the department of Environmental Engineering and Geology for their support in interpreting the measurements results on macroscopic and microscopic of thin sections performed on the analyzed salt samples. I would also like to thank the University of Petrosani, which provided the necessary equipment to perform all laboratory tests in prior experimental researches leading to the results synthesized in this article.

\section{References}

[1] Bérest, P., Ledoux, E., Legait, B., \& De Marsily, G. (1979). Effets thermiques dans les cavités en couches salifères. In $4^{\text {th }}$ ISRM Congress, (1), 31-35.

[2] Toderaş, M., Moraru, R., \& Danciu, C. (2019). Finite element method applied in mine pressure computatio within the context of rock massif support system interaction. Mining of Mineral Deposits, 13(1), 39-48. https://doi.org/10.33271/mining13.01.039

[3] Toderas, M., \& Danciu, C. (2017). Stability analysis methods of underground mining works. Saarbrücken, Germany: Lambert Academic Publishing, International Publishing House.

[4] Khalymendyk, I., \& Baryshnikov, A. (2018). The mechanism of roadway deformation in conditions of laminated rocks. Journal of Sustainable Mining, 17(2), 41-47. https://doi.org/10.1016/j.jsm.2018.03.004

[5] Shashenko, A., Gapieiev, S., \& Solodyankin, A. (2009). Numerical simulation of the elastic-plastic state of rock mass around horizontal workings. Archives of Mining Sciences, 54(2), 341-348.
[6] Hirian, C. (1982). Rock mechanics. Bucharest, Romania: Didactic and Pedagogical Publishing House Bucharest.

[7] Hudson, J., Harrison, J., \& Popescu, M. (2002). Engineering Rock Mechanics: An Introduction to the Principles. Applied Mechanics Reviews, 55(2), B30. https://doi.org/10.1115/1.1451165

[8] Lunder, P.J. (1994). Hard rock pillar strength estimation an applied empirical approach. M.Sc. Thesis. Vancouver, Canada: University of British Columbia, Faculty of Graduate Studies Department of Mining and Mineral Process Engineering.

[9] Toderaş, M. (2015). Rocks rheology in the stability of underground mining works. Study case: Sedimentary rocks from Jiu Valley, Romania. Saarbrücken, Germany: Scholars’ Press International Publishing House, Lambert Academic Publishing.

[10]Toderas, M., \& Moraru, R. (2017). The effect of increasing the water content on rocks characteristics from Şuior, Romania. Mining of Mineral Deposits, 11(3), 1-14. https://doi.org/10.15407/mining11.03.001

[11]Toderas, M. A., \& Todorescu, A. (2003). Possibility of dimensioning the pillars using the principle of interaction in the case of solid exploitation method of salt. AGIR Bulletin, (1), 40-44.

[12] Serata, S. (1968). Application of continuum mechanics to design of deep potash mines in Canada. International Journal of Rock Mechanics and Mining Sciences \& Geomechanics Abstracts, 5(4), 293-314. https://doi.org/10.1016/0148-9062(68)90002-8

[13] Todorescu, A. (1982). Rock mechanics in mining. Bucharest, Romania: Technical Publishing House.

[14] Todorescu, A. (1986). Rocks rheology. Bucharest, Romania: Technical Publishing House.

[15] Georgescu, M., Hirian, C., \& Toderaş, M. (2005). Dimensioning of the strenght elements (pillar - ceilings) afferent to the $+190 \mathrm{~m}$ and $+190 \mathrm{~m}$ levels from Praid salt mine. Environment Friendly Policy in Mining Activities. Proceedings of the First International Seminar Ecominig - Europe in $21^{\text {st }}$ Century, 97-102.

[16]Pariseau, W.G. (2011). Design analysis in rock mechanics (second edition). London, United Kingdom: CRC Press, Taylor \& Francis Group. https://doi.org/10.1201/b11461

[17] Yahya, O.M.L., Aubertin, M., \& Julien, M.R. (2000). A unified representation of the plasticity, creep and relaxation behavior of rocksalt. International Journal of Rock Mechanics and Mining Sciences, 37(5), 787-800. https://doi.org/10.1016/s1365-1609(00)00016-2

[18]Seeger, A. (1958). Kristallplastizität. Handbuch Der Physik / Encyclopedia of Physics. Berlin, Germany: Springer-Verlag. https://doi.org/10.1007/978-3-642-45890-3_1

[19]Todorescu, A., Hirian, C., Gaiducov, V., Arad, V., \& Toderaş, M. (1998). Assessment of rheological parameters through in situ measurements in pillars. Research contract Nr.10/1998.

[20] Esterhuizen, G., Dolinar, D., Ellenberger, J. \& Prosser, L. (2011). Pillar and roof span design guidelines for underground stone mines. Pittsburgh, United State: National Institute for Occupational Safety and Health. https://doi.org/10.26616/nioshpub2011171

\section{Октаедрична концепція і кубічна тривісність в оцінці вторинного напруженого стану}

\section{М. Тодерас}

Мета. Вивчення особливостей використання октаедричної концепції поведінки гірських порід і соляного масиву шляхом оцінки міцності на стиск і зсув октаедра та реологічних характеристик деформації. Оцінка в контексті кубічної тривісності кореляції між розподілом напружено-деформованого стану ціликів і стелин з можливістю забезпечення їх стійкості, що впливає на інтенсивність вилучення корисної копалини.

Методика. Виконувалися петрографічні дослідження зразків кам'яної солі із використанням мікроскопії. Механіка поведінки соляного масиву вивчалася в умовах тривісного стиску. Використано кубічне тривісне обладнання, розроблене і виконане в лабораторії механіки гірських порід з Університету Петросані. Традиційний тривісний метод був доповнений тривимірним аналізом соляного масиву при складній експлуатації камерно-стовпової системи розробки з урахуванням кубічної тривісності. Деформації соляного масиву оцінювалися в контексті циліндричної і кубічної тривісності.

Результати. Проведено аналіз деформацій соляного пласта і його реологічних властивостей на основі кубічного тривісного експериментального дослідження з урахуванням октаедричної концепції, що дозволило охарактеризувати його 3 точки зору величини природних напружених станів в трьох різних зонах: стабільній, перехідній та нестабільній. Встановлено, що коефіцієнт деформації напруженого стану октаедра солі в цілому визначає структурну стабільність розробок в соляних шахтах. Показано, що для солі з найвищим опором міцність октаедра не перевищує 5.6 МПа, що робить небезпечним застосування в соляних шахтах розрахункових величин межі міцності в $2-5$ разів більше реальної величини.

Наукова новизна. Розроблено аналітичну модель характеристики соляного масиву, що побудована на октаедричних і геомеханічних параметрах та підтверджена лабораторними дослідженнями, моделюванням і натурними вимірами. Виявлено поріг поділу для в'язко-еластичної деформації в порівнянні з в'язко-пластичною, що дозволило оцінити швидкість в'язко-пластичного сольового потоку.

Практична значимість. Визначення природного стану напружень та деформацій з урахуванням визначальної анізотропії міцності і деформації, а також реологічної поведінки солі в пласті необхідно для оцінки стійкого стану підземних споруд і елементів систем розробки соляних пластів.

Ключові слова: октаедрична концепція, тривісний, напружений стан, цүілик, сіль, реологія, взаємодія 


\section{Октаэдрическая концепция и кубическая трехосность в оценке вторичного напряженного состояния}

\section{М. Тодерас}

Цель. Изучение особенностей использования октаэдрической концепции поведения горных пород и соляного массива путем оценки прочности на сжатие и сдвиг октаэдра, реологических характеристик деформации. Оценка в контексте кубической трехосности корреляции между распределением напряженно-деформационного состояния целиков и потолочин с возможностью обеспечения их устойчивости, влияющей на интенсивность извлечения полезного ископаемого.

Методика. Выполнялись петрографические исследования образцов каменной с использованием микроскопии. Механика поведения соляного массива изучалась в условиях трехосного сжатия. Использовано кубическое трехосное оборудование, разработанное и выполненное в лаборатории механики горных пород из Университета Петросани. Традиционный трехосный метод был дополнен трехмерным анализом соляного массива при сложной эксплуатации камерно-столбовой системы разработки с учетом кубической трехосности. Деформации соляного массива оценивались в контексте цилиндрической и кубической трехосности.

Результаты. Проведен анализ деформаций соляного пласта и его реологических свойств на основе кубического трехосного экспериментального исследования с учетом октаэдрической концепции, что позволило охарактеризовать его с точки зрения величины естественных напряженных состояний в трех различных зонах: стабильной, переходной и нестабильной. Установлено, что коэффициент деформации напряженного состояния октаэдра соли в целом определяет структурную стабильность разработок в соляных шахтах. Показано, что для соли с самым высоким сопротивлением прочность октаэдра не превышает 5.6 МПа, что делает опасным применение в соляных шахтах расчетных величин предела прочности в $2-5$ раз больше реальной величины.

Научная новизна. Разработана аналитическая модель характеристики соляного массива, построенная на октаэдрических и геомеханических параметрах и подтверждена лабораторными исследованиями, моделированием и натурными измерениями. Выявлен порог разделения для вязко-эластичной деформации по сравнению с вязко-пластичной, что позволило оценить скорость вязкопластичного солевого потока.

Практическая значимость. Определение естественного состояния напряжений и деформаций с учетом определяющей анизотропии прочности и деформации, а также реологического поведения соли в пласте необходимо для оценки устойчивого состояния подземных сооружений и элементов систем разработки соляных пластов.

Ключевые слова: октаэдрическая концепция, трехосность, напряженное состояние, иелик, соль, реология, взаимодействие

\section{Article info}

Received: 31 October 2019

Accepted: 10 February 2020

Available online: 5 March 2020 